\title{
NEUROPSIHOLOŠKI PREDIKTORI KVALITETA ŽIVOTA U OBOLJELIH OD MULTIPLE SKLEROZE
}

\author{
Aida Šehanović ${ }^{1,2^{*}}$, Dževdet Smajlović ${ }^{1,2}$, Emir Tupković ${ }^{2,3}$, Omer Ć. Ibrahimagić ${ }^{1,2}$, Suljo Kunić ${ }^{2,3}$, \\ Zikrija Dostović ${ }^{1,2}$, Emina Zoletić ${ }^{4}$, Zejneba Pašić ${ }^{1,2}$ \\ ${ }^{1}$ Klinika za neurologiju, Univerzitetsko klinički centar Tuzla, Prof. dr. Ibre Pašića bb, 75000 Tuzla, BiH. \\ ${ }^{2}$ Medicinski fakultet, Univerzitet u Tuzli, Univerzitetska 1, 75000 Tuzla, BiH. \\ ${ }^{3}$ Centar za neurologiju, Dom zdravlja Tuzla, Albina i franje Herljevića 1, 75000 Tuzla, BiH. \\ ${ }^{4}$ Research Centre of Epidemiology and Statistics, Sorbonne Paris Cité, Paris, Francuska
}

Rad je primljen 11.09.2020.. Rad je recenziran 14.09.2020. Rad je prihvaćen 19.09.2020.

\section{SAŽETAK}

Uvod: Multipla skleroza (MS) je hronično, inflamatorno, (auto)imunološko oboljenje centralnog nervnog sistema (CNS). Neurospihološki poremećaji dosta često se nalaze kod pacijenata sa multiplom sklerozom i imaju refleskiju na kvalitetu života pacijenata.

Cilj istraživanja bio je uticaj neuropsiholoških poremećaja na kvalitet života kod pacijenata sa multiplom sklerozom.

Metode: Prospektivnim istraživanjem obuhvaćeno je 135 ispitanika oboljelih od MS i 50 zdravih ispitanika. Ispitanici su podijeljeni u tri grupe: prvu grupu su činili 85 ispitanika gdje bolest traje duže od jedne godine, drugu grupu su činili 50 ispitanika s novootkrivenom MS, treću grupu su činili 50 zdravih ispitanika. Instrumenti kliničke procjene bili su: Mini mentalni status, SF-36 skala procjene kvaliteta života, i baterija neuropsiholoških testova: Wechslerova skala inteligencije, test Revidirana Beta, Ravenove obojene progresivne matrice, Wechslerova skala pamćenja, test audio verbalnog učenja, Rey-Osterriehtov test složenog lika, test verbalne fluentnosti.

Rezultati: Upotrebom baterije neuropsiholoških testova došlo se od rezultata da su kognitivni poremećaji su zastupljeni u 40-60\% ispitanika oboljelih od MS. Vizuospacijalne, vizuokonstruktivne i vizuoperceptivne funkcije su lošije u prvoj grupi. Najviše su pogođene mnestičke funkcije (proces učenja, kratkoročnog i dugoročno pamćenje, dosjećanje, verbalno-logičko pamćenje) u obje grupe ispitanika, u rasponu od 30-60\%. Lošije kognitivne domene su u prve grupe ispitanika. Neposredno radno procesno pamćenje, pažnja, kratkoročno i logičko pamćenje je lošiji u ispitanika prve grupe. Na početku bolesti $16 \%$ je imalo smetnje verbalne fluentnosti, a kako bolest odmiče smetnje postaju izraženije. Rezultati procjene kvaliteta života pokazuju da lošiji kvalitet života u fizičkoj, mentalnoj dimenziji i ukupnom skoru imaju pacijenti sa lošijim MMSE i oni s lošijim kognitivnim funkcijama.

Zaključak: Neuropsihološki poremećaji u oboljelih od MS odnose se na oštećenje mnestičkih funkcija, izvršne funkcije i pažnju. Kognitivni poremećaji imaju negativan uticaj na kvalitet života oboljelih od MS.

Ključne riječi: multipla skleroza, neuropsihološki/kognitivni poremećaji, kvalitet života

Autor za korespondenciju: *

Doc.dr. med.sc. Aida Šehanović, neuropsihijatar

Klinika za neurologiju, Univerzitetsko klinički centar Tuzla.

Prof. dr. Ibre Pašića 1, 75000 Tuzla. Bosna i Hercegovina.

Telefon: ++ 38761721171 .

E-mail: aida.sehanovic@gmail.com 


\section{UVOD}

Multipla skleroza (MS) je hronično, inflamatorno, (auto)imunološko oboljenje centralnog nervnog sistema (CNS) čija etiološka pozadina nije u potpunosti jasna. Oboljenje krakteriše propadanje mijelinske ovojnice, aksona, kao i oligodendroglije (1). Etiološki predstavlja udruženost genetske predispozicije i disregulacije u imunom sistemu, uz uticaj različitih riziko-faktora iz okruženja (2). MS najčešća hronična onesposobljujuća bolest CNS-a kod mladih odraslih osoba, pogađa 2,3 miliona ljudi širom svijeta, dva puta je češća kod žena nego kod muškaraca i obično se javlja u mladoj dobi, odnosno oko 30 godina. Tok MS je varijabilan i nepredvidiv. Prema Nacionalnom društvu za multiplu sklerozu, postoje četiri vrste MS: klinički izolirani sindrom (CIS), relapsno-remitentna MS (RRMS), primarno progresivna MS (PPMS) i sekundarna pro-gresivna MS (SPMS). CIS je prva epizoda neuroloških simptoma uzrokovanih upalom i demijelinizacijom $u$ CNS-u, koja traje najmanje 24 sata, a koja ne zadovoljava kriterije za MS. RRMS karakterizira pojava definiranih napada (relapsa ili pogoršanja) novih ili sve većih neuroloških simptoma, praćenih periodima djelomičnog ili potpunog oporavka (remisije). U vrijeme dijagnoze, oko $85 \%$ pacijenata imalo je ovu vrstu MS. Osamdeset posto pacijenata s RRMS-om na kraju će prijeći na sekundarni progresivni kurs (SPMS), s postupnim i progresivnim pogoršanjem neurološke funkcije (akumulacija invaliditeta) s vremenom. Ako se ovaj progresivni tok dogodi od početka bolesti, bez ranih recidiva ili remisija, pacijent razvija PPMS, koji broji 10\% pacijenata (3). Simaptomi se najčešće (85-90\%) javljaju u atacima (egzarcerbacija ili remisija) ili sporo progresivno tokom vremena (4). Multipla skleroza se karakteriše različitim simptomima koji imaju veliki uticaj na kvalitetu života čak i u ranim fazama (5).

Neuropsihološki aspekti multiple skleroze (MS) evoluirali su u protekle tri decenije. Ono što se nekad smatralo rijetkom pojavom, kognitivna disfunkcija danas se smatra jednim od onesposobljavajućih simptoma bolesti, s pogubnim učincima na kvalitetu života pacijenata (6). Kognitivne funkcije su viši mentalni procesi koji obuhvataju niz različitih funkcija koje Lezak (7) dijeli u slijedeće podskupine: receptivne funkcije, pamćenje i učenje, mišljenje i ekspresivne funkcije. Mišljenje, jezičke funkcije, selektivna pažnja, pamćenje i svi oblici kognitivnih aktivnosti i ponašanja predstavljaju produkt intermedijalne obrade informacija $\mathrm{u}$ neuronskim mrežama asocijativnog korteksa i limbičkog sistema (8). Kognitivni poremećaji su heterogeni, ali novije studije upućuju na to da postoji određeni uzorak MS-vezanih kognitivnih poremećaja. Oni se uglavnom odnose na oštećenja radne sposobnosti i kratkoročno pamćenje, izvršne funkcije i pažnju, dok je globalna intelektualna efikasnost kasnije smanjena (9).

Svjetska zdravstvena organizacija (SZO) definše kvalitet života (KŽ) kao percepciju života pojedinca u kontekstu sistema kulture i vrijednosti u kojem živi, kao i u odnosu na njihove ciljeve, očekivanja, standarde i brige. Neke se definicije kvaliteta života fokusiraju na subjektivnu perspektivu zdravstvenog stanja pacijenta $(10,11)$ dok su druge konstrukcije šire i uključuju objektivne pokazatelje zdravlja, stanovanja i drugih materijalnih prilika (12). Većina istraživača vjeruje da su za utvrđivanje konstrukcije neophodne i subjektivne i objektivne informacije (13). Većina modela KŽ odražava višedimenzionalni konceptualni pristup, koji često uključuje fizičke, mentalne, socijalne i funkcionalne aspekte zdravlja. Izvan ovih osnovnih dimenzija, mnoge mjere uključuju varijable specifične za bolest ili liječenje (14). Kombinacija recidiva, aktivnost tjelesnog invaliditeta i aktivnost magnetne rezonance (MRI) odražavaju samo dio utjecaja koji MS ima na svakodnevni život pacijenta. Posljednjih decenija mjerenja KŽ također se razmatraju kao sve važnija za procjenu napredovanja bolesti, odgovor na liječenje i nivo pomoći koju zahtijevaju pacijenti sa MS (15). Najmanje četiri dimenzije moraju biti uključene u praćenju KŽ: fizička, funkcionalna, psihička i socijalna. Fizička dimenzija zdravlja upućuje prvenstveno na vezu bolest, tretman i simptom. Funkcionalno zdravlje uključuje brigu o sebi, pokretnost i nivo fizičke aktivnosti kao i nošenje različitih uloga u porodici ili na poslu. Kognitivno funkcionisanje, emocionalni status i generalno shvatanje zdravlja, blagostanja, 
životne satisfakcije i sreće, su centralne komponente psihičkog područja KŽ. Socijalno funkcionisanje uključuje procjenu kvalitativnih i kvantitativnih aspekata socijalnih kontakata i interakcije (16).

\section{ISPITANICI I METODE}

Istraživanje je prospektivno provedeno $\mathrm{u}$ Univerzitetsko kliničkom centru Tuzla, u Klinici za neurologiju u trajanu od 2.5 godina. Uzorak je obuhvatao 135 ispitanika oboljelih od MS i 50 zdravih ispitanika. Ispitanici su podijeljeni u tri grupe: prvu (I) grupu su činili 85 pacijenata gdje MS bolest traje duže od jedne godine, drugu (II) grupu su činili 50 pacijenata s dijagnozom novootkrivene MS (bolest ne traje duže od jedne godine), treću (III) grupu su činili 50 zdravih ispitanika prilagođenih eksperimentalnim grupama prema dobu, spolu i obrazovanju. Uključujući kriteriji za prvu grupu ispitanika su definitivno postavljena dijagnoza MS prema važećim McDonaldovim kriterijumima i učinjena magnetna rezonanca (MR) mozga najviše jednu godinu prije datuma prvog testiranja. Za drugu grupu uključujući kriteriji su postojanje dijagnoze novootkrivene MS prema revidiranim McDonaldovim kriterijumima iz 2011 (17). Uključujući kriterij za treću grupu su ispitanici koji nemaju simptome i znake neuroloških bolesti, niti kognitivne poremećaje ranije medicinski dokumentovane. Isključujući kriteriji za prvu i drugu grupu su pridružene bolesti i povrede mozga i kičmene moždine (povrede, metabolički poremećaji, epilepsija, vaskularne lezije). Svakom ispitaniku koji je zadovoljio kriterije za uključivanje u studiju analizirani su demografski podaci (godine, spol, stepen obrazovanja.

Instrumenti kliničke procjene bili su: Mini mentalni status (MMSE) (18); SF-36 skor (19). Testovi za procjenu kognitivnih funkcija: Wechslerova skala inteligencije WB-II (20), Test Revidirana Beta (21), Ravenove obojene progresivne matrice- Test intelektualnih sposobnosti (22), Wechslerova skala pamćenja (23), Test audio verbalnog učenja (AVLT) $(24,25)$, Rey-Osterriehtov test složenog lika - RCFT $(26,27)$, Test verbalne fluentnosti - FAS $(28,29)$.

U Wechslerovoj skali a inteligencije korištena su dva podtesta (zajednički pojam i sastavljanje kocki) za procjenu apstraktnog mišljenja. Test Revidirana
Beta-subtest Labirint ispituje prostornu orijentaciju i egzekutivne sposobnosti. Ravenove obojene progresivne matrice-Test intelektualnih sposobnosti uključuju sposobnosti razumijevanja kompleksnih situacija, sposobnosti pronalaženja značenja u događajima, sposobnosti percepcije i mišljenja. Wechslerova skala pamćenja ispituje neposredno i odgođeno pamćenje. Test auditivno verbalnog učenja (AVLT) je mjera neposrednog pamćenja verbalnog nepovezanog materijala. Rey-Osterriehtov test složenog lika - RCFT služi za ispitivanje vizuoperceptivne, vizuospacijalne, konstruktivne funkcije i vizuelnog pamćenja. Test verbalne fluentnosti-FAS mjeri verbalnu fluentnost koja je osjetljiva na organske disfunkcije.

MMSE služi za procjenu sljedećih kognitivnih funkcija: orijentacija, ponavljanje, računanje, kratkoročno pamćenje, imenovanje, čitanje, pisanje, izvršavanje složenih naredbi i kopiranje. Ukupan skor je 30. Kognitivno funkcionisanje prema MMSE će se gradirati kao normalno ako je skor 25-30.

SF 36 je kratki uputnik procjene zdravlja, sastoji iz 36 pitanja koja su podijeljena u osam oblasti (fizička funkcija, ograničenja fizičke funkcije, tjelesna bol, socijalno funkcionisanje, opšte mentalno zdravlje, emocionalna ograničenja, vitalnost i zamor, opšti osjećaj zdravlja). Pruža dvije opće mjere funkcije: sažetak fizičke komponente (PCS) i sažetak mentalne komponente (MCS). Svako pitanje se boduje od 1 do 100 , a rezultati blizu 100 ukazuju na bolji kvalitet života.

Ispitanicima iz sve tri grupe je obavljeno bazično testiranje a kontrolno testiranje za sve grupe ispitanika se učinilo jednu godinu nakon primarnog testiranja.

\section{STATISTIČKA OBRADA}

Uradilo se testiranje svake varijable za pripadnost normalnoj distribuciji. Za procjenu statističke značajnosti razlika dobijenih rezultata koristili smo: Mann Whitney U test, Wilcoxon i Hi-kvadrat test. Povezanost varijabli, skala, skorova i domena je ispitivana korelacionom analizom (Spearman-ov koeficijent korelacije). Statistički testovi su radjeni sa nivoom statističke vjerovatnoće od $95 \%$ ili $99 \%$ $(\mathrm{p}<0,05$ ili $\mathrm{p}<0,01)$. 


\section{REZULTATI}

Demografske i kliničke karakteristike sve tri grupe ispitanika su prikazane u Tabeli 1. Prvu grupu ispitanika činili su pacijenti sa dijagnozom MS dužom od jedne godine, njih 85 . Žena je bilo $60(70,5 \%)$ a muškaraca 25 (29,5\%). Prosječna dob ispitanika bila je 42.0+/-9.3 godina. U drugoj grupi ispitanika bili su pacijenti sa novootkrivenom MS. Obuhvatala je 50 ispitanika, žene je bilo 41 (82\%) a muških 9 (18\%). Prosječna dob ispitanika sa novootkrivenom MS bila je 37.5+/-10.8 godina. Grupa zdravih ispitanika (kontrolna grupa) su imali usklađene demografske karakteristike sa studijskim ispitanicima prve dvije grupe. U radu smo imali $82 \%$ ispitanika sa relaps-remitentnim tipom i $18 \%$ ispitanika sa sekundarno-progresivnim tipom bolesti.

Tabela 1. Demografske i kliničke karakteristike ispitanika.

\begin{tabular}{|c|c|c|c|c|c|c|}
\hline & \multicolumn{3}{|c|}{ Inicijalno testiranje } & \multicolumn{3}{|c|}{ Testiranje za jednu godinu } \\
\hline & Kontrola & $>1$ god. & $<1$ god. & Kontrola & $>1$ god. & $<1$ god. \\
\hline Broj ispitanika & 50 & 85 & 50 & 50 & 80 & 45 \\
\hline RRMS & 0 & 71 & 50 & 0 & 66 & 45 \\
\hline SPMS & 0 & 14 & 0 & 0 & 14 & 0 \\
\hline Dob u godinama & $38 \pm 5,8$ & $42 \pm 9,3$ & $37,5 \pm 10,8$ & $39 \pm 5,8$ & $43 \pm 9,3$ & $38,5 \pm 10,8$ \\
\hline $\operatorname{Spol}\left(+/{ }^{\wedge}\right)$ & $35 / 15$ & $60 / 25$ & $41 / 9$ & $35 / 15$ & $59 / 21$ & $39 / 6$ \\
\hline Edukacija u godinama & $16 \pm 1,8$ & $12 \pm 2,5$ & $12 \pm 2,4$ & $16 \pm 1,8$ & $12 \pm 2,5$ & $12 \pm 2,4$ \\
\hline EDSS & 0 & $2,5 \pm 2,3$ & $1,9 \pm 1,8$ & 0 & $3 \pm 2,6$ & $1,6 \pm 1,5$ \\
\hline Trajanje bolesti u god. & 0 & $6 \pm 4,0$ & $<1$ & 0 & $7 \pm 4,0$ & 1 \\
\hline
\end{tabular}

RRMS-relapsno-remitentna multipla skleroza; SPMS-sekundarno-progresivna multipla skleroza; EDSS - Standardizovana Kurtzkeova proširena skala stanja invaliditeta u multiploj sklerozi (eng. Expanded Disability Status Scale).

Ispitanici prve i druge grupe su pokazali oštećenje kvaliteta života u fizičkoj, mentalnoj dimenziji i ukupnom SF 36 skoru Tabela 2.

Tabela 2. Distribucija pojedinih dimenzija kvaliteta života za prvu i drugu grupu ispitanika.

\begin{tabular}{|c|c|c|c|c|c|}
\hline & & \multicolumn{2}{|c|}{ Grupa I (> 1 god.) } & \multicolumn{2}{|c|}{ Grupa II (<1 god.) } \\
\hline & & Test I & Test II & Test I & Test II \\
\hline & & $\mathrm{n}=85$ & $\mathrm{n}=80$ & $\mathrm{n}=50$ & $\mathrm{n}=45$ \\
\hline \multirow{11}{*}{ SF 36} & Fizička funkcija & 56,9 & 54,9 & 70,1 & 74,2 \\
\hline & Fizička ograničenja & 47,9 & 50,3 & 50 & 57,2 \\
\hline & Tjelesna bol & 80 & 78,5 & 85 & 86,2 \\
\hline & Opšte zdravlje & 54,6 & 52,9 & 57 & 58,0 \\
\hline & Vitalnost & 48,9 & 46,2 & 53 & 55,7 \\
\hline & Socijalno funkcioniranje & 69,8 & 65,9 & 63 & 68,1 \\
\hline & Emocionalna ograničenja & 63,5 & 65,4 & 61 & 64,4 \\
\hline & Mentalno funkcionisanje & 68 & 68,5 & 65 & 68,8 \\
\hline & Fizičko zdravlje & 57,7 & 56,6 & 63 & 66,2 \\
\hline & Mentalno zdravlje & 60.9 & 59,8 & 60 & 62,9 \\
\hline & Ukupni skor & 61,2 & 60,3 & 63 & 66,5 \\
\hline
\end{tabular}

U tabeli 2 je prikazana distribucija svih osam dimenzija kvaliteta života za prvu i drugu grupu ispitanika. Uočava se da su kod druge grupe ispitanika najmanje oštećena fizička ograničenja. Ispitanici prve grupe ispoljavaju veća fizička ograničenja, vitalnost je lošija i ukupno zdravlje. Obje grupe ispitanika imaju mentalne smetnje, koje su moguće posljedica suočavanja s teškom bolešću a dijelom i posljedica topografske distribucije demijelinizacijskih lezija mozga.

Distribucija kognitivnih poremećaja oboljelih od multiple skleroze prikazana je u Tabeli 3. u dvije studijske grupe ispitanika (prva i druga grupa) nakon inicijalnog testiranja i jednu godinu kasnije. 
Šehanović A, Smajlović Dž, Tupković E, Ibrahimagić O, Kunić S, Dostović Z, i sur. Neuropsihološki prediktori kvaliteta života u oboljelih od multiple skleroze. Zdravstveni glasnik. 2020;6(2):42-52.

Tabela 3. Distribucija kognitivnih poremećaja ispitanika studijskih grupa.

\begin{tabular}{|c|c|c|c|c|c|c|c|c|}
\hline \multirow{14}{*}{$\begin{array}{l}\text { Prva grupa } \\
\text { (bolest traje } \\
\text { duže od go- } \\
\text { dinu) }\end{array}$} & & & \multicolumn{3}{|c|}{ Prvo testiranje $(\mathrm{n}=85)$} & \multicolumn{3}{|c|}{ Drugo testiranje $(\mathrm{n}=80)$} \\
\hline & \multicolumn{2}{|l|}{ Test } & Uredan & $\begin{array}{l}\text { Ispod pros- } \\
\text { jeka }\end{array}$ & Patološki & Uredan & \begin{tabular}{|l|}
$\begin{array}{l}\text { Ispod } \\
\text { jeka }\end{array}$ \\
\end{tabular} & Patološki \\
\hline & \multicolumn{2}{|l|}{$\mathrm{W} \mathrm{k}$} & 58,82 & \begin{tabular}{|l|l|}
14,12 \\
\end{tabular} & 27,06 & 62,50 & 15,00 & 22,50 \\
\hline & \multicolumn{2}{|l|}{ W zp } & 38,82 & 54,12 & 7,06 & 32,50 & 61,25 & 6,25 \\
\hline & \multicolumn{2}{|l|}{ CPM } & 96,47 & 2,35 & 1,18 & 92,50 & 0,00 & 7,50 \\
\hline & \multicolumn{2}{|l|}{$\mathrm{B}$} & 65,88 & 12,94 & 21,18 & 71,25 & 10,00 & 18,75 \\
\hline & \multicolumn{2}{|l|}{ W np } & 38,82 & 32,94 & 28,24 & 28,75 & 38,75 & 32,50 \\
\hline & \multicolumn{2}{|l|}{ W lp } & 41,18 & 10,59 & 48,24 & 41,25 & 15,00 & 43,75 \\
\hline & \multicolumn{2}{|l|}{ AVLT 1-5 } & 49,41 & 21,18 & 29,41 & 42,50 & 21,25 & 36,25 \\
\hline & \multicolumn{2}{|l|}{ AVLT 6} & 22,35 & 20,00 & 57,65 & 21,25 & 23,75 & 55,00 \\
\hline & \multicolumn{2}{|l|}{ AVLT 7} & 21,18 & 17,65 & 61,18 & 21,25 & 20,00 & 58,75 \\
\hline & \multicolumn{2}{|l|}{ RCFT Rt } & 56,47 & 8,24 & 35,29 & 58,75 & 5,00 & 36,25 \\
\hline & \multicolumn{2}{|l|}{ RCFT vp } & 36,47 & 9,41 & 54,12 & 36,25 & 16,25 & 47,50 \\
\hline & \multicolumn{2}{|l|}{ FAS } & 65,88 & 5,88 & 28,24 & 71,25 & 7,50 & 21,25 \\
\hline \multirow{2}{*}{\multicolumn{2}{|c|}{ Test }} & & \multicolumn{3}{|c|}{ Prvo testiranje $(\mathrm{n}=50)$} & \multicolumn{3}{|c|}{ Drugo testiranje $(n=45)$} \\
\hline & & $\begin{array}{l}\text { Ure- } \\
\text { dan }\end{array}$ & \begin{tabular}{|l|} 
Ispod prosje- \\
$\mathrm{ka}$
\end{tabular} & Patološki & Uredan & $\begin{array}{l}\text { Ispod prosje- } \\
\text { ka }\end{array}$ & Patološki & \\
\hline \multirow{12}{*}{$\begin{array}{l}\text { Druga grupa } \\
\text { (novodijag- } \\
\text { nosticirani } \\
\text { pacijenti) }\end{array}$} & \multicolumn{2}{|l|}{$\mathrm{Wk}$} & 80,00 & 8,00 & 12,00 & 77,78 & 13,33 & 8,89 \\
\hline & \multicolumn{2}{|l|}{ W zp } & 44,00 & 46,00 & 10,00 & 28,89 & 64,44 & 6,67 \\
\hline & \multicolumn{2}{|l|}{ CPM } & 94,00 & 4,00 & 2,00 & 95,56 & 4,44 & 0,00 \\
\hline & \multicolumn{2}{|l|}{$\mathrm{B}$} & 80,00 & 6,00 & 14,00 & 82,22 & 8,89 & 8,89 \\
\hline & \multicolumn{2}{|l|}{$\mathrm{W} n \mathrm{p}$} & 50,00 & 36,00 & 14,00 & 44,44 & 31,11 & 24,44 \\
\hline & \multicolumn{2}{|l|}{ W lp } & 46,00 & 16,00 & 38,00 & 42,22 & 20,00 & 37,78 \\
\hline & \multicolumn{2}{|l|}{ AVLT 1-5 } & 54,00 & 22,00 & 24,00 & 42,22 & 33,33 & 24,44 \\
\hline & \multicolumn{2}{|l|}{ AVLT 6} & 26,00 & 26,00 & 48,00 & 24,44 & 28,89 & 46,67 \\
\hline & \multicolumn{2}{|l|}{ AVLT 7} & 28,00 & 32,00 & 40,00 & 17,78 & 28,89 & 53,33 \\
\hline & \multicolumn{2}{|l|}{ RCFT Rt } & 74,00 & 12,00 & 14,00 & 75,56 & 4,44 & 20,00 \\
\hline & \multicolumn{2}{|l|}{ RCFT vp } & 48,00 & 10,00 & 42,00 & 53,33 & 13,33 & 33,33 \\
\hline & FAS & & 76,00 & 8,00 & 16,00 & 71,11 & 15,56 & 13,33 \\
\hline
\end{tabular}

W k - Wechsler skala inteligencije-podtest kocke; W zp - Wechsler skala inteligencije-podtest zajednicki pojmovi; CPM - Ravenove obojene progresivne matrice - CPM; $\beta$ - Test Revidirana beta labirint; W np - Wechslerova skala pamćenja - numeričko pamćenje; W lp - Wechslerova skala pamćenja - logičko pamćenje; Test AVLT A1-A5; Test AVLT A6; Test AVLT A7; RCFT Rt - Rey test složenog lika RCFT; RCFT vp - RCFT vizuelno pamćenje dosjećanje; FAS test verbalne fluentnosti.

Grupa zdravih ispitanika imala je uredne razultaten neuropsiholoških testova. Ispitanici prve i druge grupe pokazuju statistički značajna odstupanja u svim neuropsihološkim testovima u odnosu na kontrolnu grupu zdravih, koji su pokazali uredne skorove.

Kratkoročno pamćenje (A6) je značajno narušeno u obje grupe ispitanika, u prvoj grupi $57 \%$ ispitanika a u drugoj grupi 48\% ima narušeno kratkoročno verbalno pamćenje. Obje grupe ispitanika pokazuju oštećenje dugoročnog pamćenja (zaboravljanje verbalnog materijala-A7), i to u prvoj grupi $61 \%$ a u drugoj grupi $40 \%$ ispitanika je pokazalo znake zaboravljanja. Na testovima neverbalnog dosjećanja (RCFT Rey test dosjećanje) uočena su značajna odstupanja i odnose se na neposredno vizuelno dosjećanje, perceptivno-analitičku i organizacijsku sposobnost koja je u prvoj grupi ispitanika oštećenja u 54\% a u drugoj grupi u $42 \%$ ispitanika. Neposredno radno procesno pamćenje (trenutno učenje), pažnja i kratkoročno pamćenje je oštećeno u 28.2\% ispitanika prve grupe, i u $16 \%$ ispitanika druge grupe. Logičko pamćenje oštećeno je u prvoj grupi ispitanika u $48.2 \%$ a u drugoj grupi $38 \%$ ispitanika. Neposredno pamćenje verbalnog nepovezanog materijala na krivulji učenja (AVLT A1-A5) pokazuje da oko 30\% ispitanika obje grupe ima patološki skor. 
Šehanović A, Smajlović Dž, Tupković E, Ibrahimagić O, Kunić S, Dostović Z, i sur. Neuropsihološki prediktori kvaliteta života u oboljelih od multiple skleroze. Zdravstveni glasnik. 2020;6(2):42-52.

Verbalna fluentnost (FAS) kao jednog od pokazatelja egzekutivnih funkcija kod organskih oštećenja mozga, u ovom slučaju usljed demijelinizacijskih lezija, je u prvoj grupi ispitanika oštećenja u $28.2 \%$, a u drugoj grupi u 16\% ispitanika. Vizuospacijalne, vizuokostruktivne i vizuoperceptivne sposobnosti su lošije u ispitanika prve grupe. Apstraktno mišljenje i opšta intelektualna sposobnost ostaju najduže očuvani u obje grupe oboljelih ispitanika.

Rezultati pokazuju da MMSE nije dovoljno osjetljiva metoda za procjenu kognitivnih funkcija u MS pacijenata. U prvoj i drugoj grupi ispitanika pokazao uredne vrijednosti u preko $85 \%$ ispitanika.

Tabela 4. Korelacija SF 36 sa rezultatima psiholoških testova dvije studijske grupe ispitanika.

\begin{tabular}{|c|c|c|c|c|c|c|c|}
\hline \multirow{15}{*}{$\begin{array}{l}\text { Prva grupa } \\
\text { (bolest traje duže } \\
\text { od godinu) }\end{array}$} & & \multicolumn{3}{|c|}{ Prvo testiranje $(\mathrm{n}=85)$} & \multicolumn{3}{|c|}{ Drugo testiranje $(\mathrm{n}=80)$} \\
\hline & Test & $\begin{array}{c}\begin{array}{c}\text { Fizička di- } \\
\text { menzija }\end{array} \\
\text { Rho }(\ldots \mathrm{p})\end{array}$ & $\begin{array}{c}\text { Mentalna } \\
\text { dimenzija } \\
\text { Rho }\end{array}$ & $\begin{array}{c}\text { Ukupni skor } \\
\text { Rho }{ }^{(\ldots . . p)}\end{array}$ & $\begin{array}{c}\text { Fizička di- } \\
\text { menzija } \\
\text { Rho }(\ldots \mathrm{p})\end{array}$ & $\begin{array}{c}\text { Mentalna } \\
\text { dimenzija } \\
\text { Rho }\end{array}$ & $\begin{array}{c}\text { Ukupni skor } \\
\text { Rho }{ }^{(\ldots . . p)}\end{array}$ \\
\hline & MMSE & $0,5062 * *$ & $0,4392 * *$ & $0,4832 * *$ & $0,4282 * *$ & $0,4472 * *$ & $0,4371 * *$ \\
\hline & $\mathrm{W} \mathrm{k}$ & $0,4405 * *$ & $0,3509 * *$ & $0,4046 * *$ & $0,4292 * *$ & $0,3464 * *$ & $0,3918 * *$ \\
\hline & W zp & $0,3352 * *$ & $0,2936 * *$ & $0,3256^{* *}$ & $0,4244 * *$ & $0,4220 * *$ & $0,4119 * *$ \\
\hline & CPM & $0,3947 * *$ & $0,3325 * *$ & $0,3775 * *$ & $0,5009 * *$ & $0,4556^{* *}$ & $0,4778 * *$ \\
\hline & $\mathrm{B}$ & $0,3678 * *$ & $0,2993 * *$ & $0,3383 * *$ & $0,4304 * *$ & $0,3424 * *$ & $0,3922 * *$ \\
\hline & $\mathrm{W} n \mathrm{np}$ & $0,2922 * *$ & 0,1392 & $0,2058 *$ & $0,3765 * *$ & $0,3711 * *$ & $0,3646 * *$ \\
\hline & W lp & $0,3770 * *$ & $0,3187 * *$ & $0,3471 * *$ & $0,3208 * *$ & $0,3150 * *$ & $0,3055^{* *}$ \\
\hline & AVLT 1-5 & $0,4424 * *$ & $0,3757 * *$ & $0,4265 * *$ & $0,2808 *$ & $0,3019 * *$ & $0,2740 *$ \\
\hline & AVLT 6 & $0,4302 * *$ & $0,3205 * *$ & $0,4029 * *$ & $0,2913 * *$ & $0,3098 * *$ & $0,2892 * *$ \\
\hline & AVLT 7 & $0,4095 * *$ & $0,2985 * *$ & $0,3739 * *$ & $0,2279 *$ & $0,2524 *$ & $0,2257 *$ \\
\hline & RCFT Rt & $0,3590 * *$ & $0,2356^{*}$ & $0,2882 * *$ & $0,5302 * *$ & $0,5085 * *$ & $0,5269 * *$ \\
\hline & RCFT vp & $0,3931 * *$ & $0,3215^{* *}$ & $0,3655 * *$ & $0,4435^{* *}$ & $0,4398 * *$ & $0,4367 * *$ \\
\hline & FAS & $0,3685 * *$ & $0,3398 * *$ & $0,3675 * *$ & $0,3051 * *$ & $0,3057 * *$ & $0,3258 * *$ \\
\hline & & Prvo testiranj & $(n=50)$ & & Drugo testira & je $(n=45)$ & \\
\hline & Test & $\begin{array}{c}\begin{array}{c}\text { Fizička di- } \\
\text { menzija }\end{array} \\
\text { Rho }(\ldots \mathrm{p}) \\
\end{array}$ & $\begin{array}{c}\begin{array}{c}\text { Mentalna } \\
\text { dimenzija }\end{array} \\
\text { Rho }{ }^{(\ldots . . p)} \\
\end{array}$ & $\begin{array}{c}\text { Ukupni skor } \\
\text { Rho }\end{array}$ & $\begin{array}{c}\begin{array}{c}\text { Fizička di- } \\
\text { menzija }\end{array} \\
\text { Rho }(\ldots \mathrm{p}) \\
\end{array}$ & $\begin{array}{c}\begin{array}{c}\text { Mentalna } \\
\text { dimenzija }\end{array} \\
\text { Rho }{ }^{(\ldots . . p)} \\
\end{array}$ & $\begin{array}{c}\text { Ukupni skor } \\
\text { Rho }{ }^{(\ldots . p)}\end{array}$ \\
\hline & MMSE & $0,3233^{*}$ & $0,3814 * *$ & $0,3588^{*}$ & $0,5319 *$ & $0,6108 * *$ & $0,5868 * *$ \\
\hline & $\mathrm{W} \mathrm{k}$ & $0,3821 * *$ & $0,3883 * *$ & $0,3892 * *$ & 0,2722 & $0,3341 *$ & $0,3158^{*}$ \\
\hline & W zp & $0,3237 *$ & $0,3791 * *$ & $0,3628 *$ & $0,3693 *$ & $0,4002 * *$ & $0,3560 *$ \\
\hline Druga grupa & CPM & $0,3644 *$ & $0,3628 *$ & $0,3707 * *$ & 0,2752 & $0,3367 *$ & 0,2876 \\
\hline (novodijagnostici- & B & 0,1792 & 0,1868 & 0,2007 & 0,2902 & 0,2918 & 0,2938 \\
\hline rani acijenti) & $\mathrm{W} n \mathrm{p}$ & 0,2789 & $0,3125^{*}$ & $0,3095^{*}$ & $0,3158^{*}$ & $0,4036 * *$ & $0,3963 * *$ \\
\hline & W lp & $0,3810 * *$ & $0,3495^{*}$ & $0,3829 * *$ & 0,2738 & $0,3267 *$ & $0,3171 *$ \\
\hline & AVLT 1-5 & $0,3451 *$ & $0,3228 *$ & $0,3432 *$ & $0,3974 * *$ & $0,4725 * *$ & $0,4192 * *$ \\
\hline & AVLT 6 & $0,4134 * *$ & $0,4140 * *$ & $0,4345 * *$ & $0,3496^{*}$ & $0,4140 * *$ & $0,3812^{*}$ \\
\hline & AVLT 7 & $0,4054 * *$ & $0,4340 * *$ & $0,4376 * *$ & $0,3299 *$ & $0,3896 * *$ & $0,3648 *$ \\
\hline & RCFT Rt & $0,3838 * *$ & $0,4232 * *$ & $0,4280 * *$ & $0,3168 *$ & $0,4542 * *$ & $0,4010 * *$ \\
\hline & RCFT vp & $0,3018^{*}$ & $0,3741 * *$ & $0,3530 *$ & $0,2997^{*}$ & $0,4432 * *$ & $0,3591 *$ \\
\hline & FAS & $0,3373 *$ & $0,4103 * *$ & $0,3722 * *$ & $0,3861 * *$ & $0,4527 * *$ & $0,4275^{* *}$ \\
\hline
\end{tabular}

SF 36 - Opšti generički upitnik za mjerenje kvaliteta života (eng. Short form 36); MMSE - mini - mental status upitnik; W k - Wechsler skala inteligencije-subtest kocke; W zp - Wechsler skala inteligencije-subtest zajednicki pojmovi; CPM - Ravenove obojene progresivne matrice - CPM; $\beta$ - Test Revidirana beta labirint; W np - Wechslerova skala pamcenja - numericko pamcenje; W lp - Wechslerova skala pamćenja - logičko pamćenje; Test AVLT A1-A5; Test AVLT A6; Test AVLT A7; RCFT Rt - Rey test složenog lika RCFT; RCFT vp - RCFT vizuelno pamćenje dosjećanje; FAS test; Rho - Spermanov koeficijent korelacije ranga; * - mogućnost slučajne greške dvosmjerno testirane hipoteze $(\mathrm{p}<0.05)$; ** mogućnost slučajne razlike dvosmjerno testirane hipoteze $(\mathrm{p}<0.01)$. 
Za obje studijske grupe u prvom i drugom testiranju prikazana je u Tabeli 4. korelacija rezultata SF 36 (fizičke i mentalne dimenzije kao i ukupnog skora kvaliteta života) sa MMSE i 12 psiholoških testova (Wechsler skala inteligencije-podtest kocke, Wechsler skala intelig.subtest zajednicki pojmovi, Ravenove obojene progresivne matrice-CPM, Test Revidirana beta labirint, Wechslerova skala pamcenja-numericko pamcenje, Wechslerova skala pamcenja-logicko pamcenje, Test AVLT A1-A5, Test AVLT A6, Test AVLT A7, Rey test slozenog lika RCFT, RCFT vizuelno pamcenje i dosjecanje, FAS test).

Kod ispitanika prve grupe razultati pokazuju da lošiji kvalitet života imaju pacijenti sa lošijim MMSE i oni s lošijim kognitivnim funkcijama. Fizička, mentalna dimenzija i ukupan skor kvaliteta života prve grupe ispitanika pri prvom i drugom testiranju značajno pozitivno koreliraju sa MMSE i svim korištenim psihološkim testovima. Izutetak je kod mentalne komponente kvaliteta života i ukupnog SF 36 skora prve grupe ispitanika koji nisu u korelaciji sa testom numeričkog pamćenja (Weschslerove skale pamćenja).

Kod ispitanika druge grupe, nakon prvog i drugog testiranja fizička, mentalna dimenzija kvaliteta života kao i ukupan SF-36 skor pri oba testiranja pozitivno značajno koreliraju sa MMSE. Fizička dimenzija kvaliteta života druge grupe ispitanika pri prvom testiranju značajno korelira sa svim korištenim psihološkim testovima sem $\beta$-test (revidirana beta labirint) i Wechslerove skale pamćenja- numeričko pamćenje, a pri drugom testiranju značajno korelira sa svim korištenim psihološkim testovima sem Wechslerove skale inteligencije - podtest kocke, Ravenove obojene progresivne matrice -CPM, $\beta$-test (revidirana beta labirint) i Wechslerova skala pamćenja - logičko pamćenje. Mentalna dimenzija kao i ukupan skor kvaliteta života druge grupe ispitanika pri prvom i drugom testiranju testiranju značajno korelira sa svim korištenim psihološkim testovima sem $\beta$-testa (revidirana beta labirint). S obzirom na to da je test Revidirana beta podtest labirint uglavnom pokazatelj egzekutivnih (izvršnih) funkcija i neverbalne inteligencije, koje ostaju očuvane u početku bolesti, upravo objašnjava da ove kognitivna oštećenja ne utiču na kvalitet života ispitanika u početku bolesti.

\section{DISKUSIJA}

Multipla skleroza je neurodegenerativni progresivni poremećaj koji pogađa mlađe odrasle ljude u najproduktivnijem dobu, žene obolijevaju češće U ovoj studiji žene su zastupljenije od muškaraca u obje grupe ispitanika (u prvoj grupi 70,5\% a u drugoj grupi $82 \%$ su činile žene). Prosječna dob ispitanika prve grupe bila je $42.0+/-9.3$ godina, a druge grupe $37.5+/-10.8$ godina. Ovakav rezultat korelira sa rezultatima u drugim studijama $(3,4)$. Demografskim parametrima prve i druge grupe prilagođena je kontrolna grupa (polna, dobna distribucija, obrazovanje). Treća grupa (kontrolna grupa zdravih) imala je žena $70 \%$, a prosječna dob je bila 38,0+/-5.8. U radu smo imali $82 \%$ ispitanika sa relaps-remitentnim tipom i $18 \%$ ispitanika sa sekundarno-progresivnim tipom bolesti, u korelaciji sa drugim studijama ) (30,31).

Neuropsihološki poremećaji u MS danas se smatraju jednim od onesposobljavajućih simptoma bolesti, s pogubnim učincima na kvalitetu života pacijenata (6). Kognitivni poremećaji su prema dosadašnjim studijama uočeni u 45-60\% oboljelih od MS. U ranim fazama bolesti dovode do oštećenja radne sposobnosti, dugoročnog pamćenja, izvršnih funkcija i pažnje, dok je globalna intelektualna efikasnost kasnije smanjena $(8,32)$. Neuropsihološkom procjenom ukupna prevalenca kognitivne disfunkcije u naših ispitanika je $50 \%$ u pacijenata prve grupe i $42 \%$ ispitanika druge grupe (novootkrivena MS), što je u skladu s procijenjenom prevalencijom prijašnjih studija koje su u rasponu od $40 \%$ do $70 \%$ ) (33).

Opšte intelektualne sposobnosti, neverbalna inteligencija i egzekutivne funkcije ostaju očuvane, $\mathrm{u}$ obje grupe ispitanika, posebno u početku bolesti. Ovakvi rezultati su u korelaciji sa studijom Rao i sar. koji su našli da su egzekutivne funkcije ukupno narušene u $19 \%$ ispitanika, a u početnoj fazi bolesti se ne uočavaju u većem procentu ) (34).

Vizuospacijalne, vizuokonstruktivne i vizuoper- 
ceptivne funkcije su lošije u prvoj grupi. Prva grupa ispitanika ima lošije rezultate u kratkoročnom pamćenju, dugoročnomi logičkom pamćenu u odnosu na drugu grupu koji su na početku bolesti. Testovima pažnje se mogu uočiti nedostatci u pacijenata sa blagim do umjerenim kognitivnim oštećenjem. Studija Rahn i saradnika (35) je sličnim rezultatima opisala da osobe sa MS mogu imati oštećenu pažnju, smetnje koncentracije, poteškoće s poslovima koji zahtijevaju kontinuiranu pažnju, da ne mogu zapamtiti podatke potrebne za dovršetak zadatka a prisutna je i rastresenost.

Papathanasiou i saradnici su zaključili da se umanjenje kognitivnih funkcija pojavljuje u gotovo svim istraživanim domenama. Kognitivni status je povezan sa trajanjem bolesti, tjelesnim invaliditetom, a važno je uočiti da kognicija može predvidjeti buduće napredovanje bolesti kao što su npr. kognitivna stanja u CIS fazi predviđaju napredovanje ka MS, a kognitivni status u MS predviđa moguće taloženje tjelesnog invaliditeta (35).

Rezultati ranijih studija $(31,34)$ pokazali su relativnu očuvanost govora u početku bolesti, a do sličnih rezultata smo došli u naših ispitanika. $\mathrm{Na}$ početku bolesti (u drugoj grupi ispitanika 16\% je imalo smetnje verbalne fluentnosti), a kako bolest odmiče smetnje postaju izraženije ( $28 \%$ ispitanika prve grupe je pokazalo patološki nalaz).

Budući da su kognitivna oštećenja često prisutna u ranim fazama, rano prepoznavanje ovih problema omogućava pacijentima da se nose sa strategijama koje mogu smanjiti teret bolesti. Korištenje neuropsiholoških konsultacija moglo bi pružiti praktične informacije o tome kada i kako usmjeriti profesionalne intervencije za MS pacijente sa kognitivnim ograničenjima $(36,37)$.

Kvalitet života je multidimenzionalan koncept koji povezuje fizičko, socijalno, psihološko i emocionalno funkcionisanje. Upitnik SF-36 jednostavno ističe područja zdravlja na koja bolest utiče, može otkriti kako se pacijenti nose sa bolešću. Kognitivna oštećenja svojom refleksijom značajno utiču na kvalitet života i socijalno-emocionalno funkcionisanje. Upotrebom baterije kognitivnih testova utvrđeno je da fizička, mentalna dimenzija kao i uk- upan skor kvaliteta života druge grupe ispitanika pri prvom i drugom testiranju ne pokazuju značajnu korelaciju sa testom Revidirana beta-podtest labirint, a značajno koreliraju s drugim navedenim testovima. Egzekutivne (izvršne) funkcije i neverbalna inteligencija ostaju očuvane i ne utiču na kvalitet života ispitanika u početku bolesti. Prema studiji Rao i sar. egzekutivne funkcije su ukupno narušene u $19 \%$ ispitanika, a u početnoj fazi bolesti se ne uočavaju u većem procentu (34).

Rezultati pokazuju da lošiji kvalitet života imaju pacijenti sa lošijim MMSE i oni s lošijim kognitivnim funkcijama. Kognitivne disfunkcije smanjuju fizičku neovisnost i društvene aktivnosti, kompetentnost u svakodnevnim aktivnostima, ličnu i društvenu neovisnost, pridržavanje terapijskim protokolima, potencijalnu rehabilitaciju, sigurnost u saobraćaju. Bolesnici sa kognitivnim oštećenjem imaju veću vjerovatnoću da budu nezaposleni, dok su zaposleni pacijenti kognitivno očuvaniji (33).

\section{ZAKLJUČAK}

Multipla skleroza značajno utiče na kvalitet života smanjujući sposobnost za rad i društvene aktivnosti. Značaj procjene neuropsiholoških poremećaja i njihove refleskije na kvalitet života, udruženo sa unapređenjem neuroimidžing tehnologija, ogleda se u sveobuhvatnijem tretmanu oboljelim od MS.

\section{REFERENCE}

1. Compston A, Coles A. Multiple sclerosis. Lancet 2008; 372 (9648):1502-1517.

2. Ascherio A, Munger KL. Environmental risk factors for multiple sclerosis. Part I: the role of infection. Ann Neurol 2007;61 (4): 288-299.

3. Harbo HF, Gold R, Tnore M. Sex and gender issuse un multiple sclerosis. Ther Adv Neurol Disord 2013;6(4):237-248.

4. Wade BJ. Spatial analysis of global prevalence of multiple sclerosis suggests need for an updated prevalence scale. Mult Scler Int. 2014:124578.

5. Lublin FD, Reingold SC. Defining the clinical course of multiple sclerosis: Results of an international survey (View and Reviews). Neurology 1996;46:907-911. 
6. Ralph H.B. Benedict, John DeLuca, Christian Enzinger, Jeroen J.G. Geurts. Neuropsychology of Multiple Sclerosis: Looking Back and Moving Forward. Special Issue: Commemoration of the 50th Anniversary of the International Neuropsychological Society. 2017; Volume 23, Special Issue 9-10:832-842.

7. Lezak MD. Neuropsychological assessment (III edition), New York:Oxford University Press 1995

8. Ocić G. Teorijski osnovi savremene neuropsihologije U: Ocić G Klinička neuropsihologija. Zavod za udžbenike i nastavna sredstva Beograd, 1998;31-41.

9. Guimaraes J, Jose MS. Cognitive Dysfunction in Multiple Sclerosis. Front Neurol 2012;3:74-98.

10. WHOQOL Group. Study protocol for the World Health Organization project to develop a quality of life assessment instrument (WHOQOL). Qual Life Res (1993) 2:153-9.

11. Schipper H, Clinch JJ, Olweny CLM. Quality of life studies: definitions and conceptual issues. In: Spilker B, editor. Quality of Life and Pharmacoeconomics in Clinical Trials. Philadelphia: Lippincott-Raven; (1996). p. 11-24.

12. Gotay CC, Moore TD. Assessing quality of life in head and neck cancer. Qual Life Res (1992) $1(1): 5-17$

13. Lauer G. Concepts of quality of life in mental health care. In: Priebe S, Oliver JPJ, Kaiser W, editors. Quality of Life and Mental Health Care. Philadelphia, PA: Wrightson Biomedical; (1999). p. 19-34

14. Post MW. Definitions of quality of life: what has happened and how to move on. Top Spinal Cord Inj Rehabil (2014) 20(3):167-80.

15. Lysandropoulos AP, Havrdova E, Paradig MSG. 'Hidden' factors influencing quality of life in patients with multiple sclerosis. Eur J Neurol (2015) 22(Suppl 2):28-33.

16. Niemi ML, Laaksonen R, Kotila M, Waltimo O (1988) Quality of life 4 years after stroke. Stroke 19:1101-1107.

17. Polman C, Reingold S, Banwell B, Clanet M, Cohen J, Filippi M, Fujihara K, Havrdova E, Hut- chinson M, Kappos L, Lublin F, Montalban X, O'Connor P, Sandberg-Wollheim M, Thompson A, Waubant E, Weinshenker B, Wolinsky J. Diagnostic Criteria for Multiple Sclerosis: 2010 Revisions to the McDonald Criteria. Ann Neurol 2011;69:292-302.

18. Folstein M, Folstein SE, McHugh PR. «Mini-Mental State» a practical method for granding the cognitive state of patients for the clinician. J Psychiat 1975;12(3):189-198.

19. Ware JE, Snow KK, Kosinski M, Gandek B. SF-36 health survey manual and interpretation guide. The Health Institute. Boston,1993 MA:Nimrod Press.

20. Wechsler D. Manual for the Wechsler Adult Intelligence Scale. The Psychological corporation, New York, 1955

21. Kellogg CE, Morton NW, Lindner RM, Gurvitz M. Revised Beta Examination: Manual. NY: Psychological Corp, 1946.

22. Raven J, Raven JC, Court JH. Priručnik za Ravenove progresivne matrice i ljestvice rječnika. 2. dio. Obojene progresivne matrice. Naklada Slap, Jastrebarsko, 1994.

23. Wechsler D. Wechsler memory scale. The Psychological corporation. New York, 1945.

24. Rey A. Lexamen clinique in psychologie. Press Universitaire de France, Paris, 1964.

25. Taylor EM. Neuropsychology. Harvard University Press, Cambridge MA, 1959.

26. Osterrieth PA. "The test of copying a complex figure: A contribution to the study of perception and memory". Archives de Psychologie 1944;30: 286-356.

27. Meyers JE and Meyers KR. Rey Complex Figure Test and Recognition Trial: Professional manual. Lutz FL: Psychological Assessment Resources, 1995.

28. Benton AL. Differential behavioral effects in frontal lobe disease. Neuropsychol 1968;6: 5360.

29. Benton AL, Hamsher K, Sivan AB. Multilingual aphasia examination. Iowa City, 1976. Wingerchuk DM, Lucchinetti CF, Noseworthy JH. Multiple sclerosis: current pathophysiological 
concept. Lab Invest 2001;81:263-281.

30. Kristen R, Slusher B, Kaplin A. Cognitive Impairment in Multiple Sclerosis: A Forgotten Disability remembered. Cerebrum 2012; vol.14:4560.

31. Chiaravalloti ND, DeLuca J. Cognitive impairment in multiple sclerosis. Lancet Neurol 2008; 7:1139-1151.

32. Denney DR, Sworowski LA, Lynch SG. Cognitive impairment in three subtypes of multiple sclerosis. Arch Clin Neuropsychol 2005;20 (8):967-981.

33. Papathanasiou A, Messinis L, Georgiou VL, Papathanasopoulos1P. Cognitive Impairment in Relapsing Remitting and Secondary Progressive Multiple Sclerosis Patients: Efficacy of a Computerized Cognitive Screening Battery Neurology, vol (2014), Published 13 March 2014, Article ID 151379, 7 pages.
34. Rao SM, Leo GJ, Ellington L, Nauertz T, Bernardin L, Unveragt F. Cognitive dysfunction in multiple sclerosis. Impact on employment and social functioning. Neurol 1991;41:692-696.

35. Rahn K, Slusher B and Kaplin A (2012) Cognitive impairment in Multiple sclerosis: A Forgotten Disability Remembered. Cerebrum (14): PMC3574761

36. Hämäläinen $\mathrm{P}$, Rosti-Otajärvi E. Cognitive impairment in MS: Rehabilitation approaches. Acta Neurol Scand. 2016; 134(Suppl. 200): 8-13.

37. Feuillet L, Reuter F, Audoin B, et al. Early cognitive impairment in patients with clinically isolated syndrome suggestive of multiple sclerosis. Mult Scler. 2007; 13(1): 124-127. 


\title{
NEUROPSYCHOLOGICAL PREDICTORS OF QUALITY OF LIFE IN PATIENTS WITH MULTIPLE SCLEROSIS
}

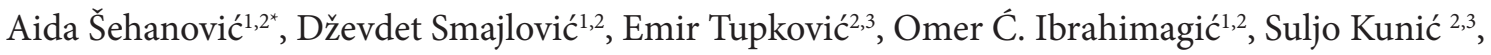 \\ Zikrija Dostović, ${ }^{1,2}$, Emina Zoletić ${ }^{4}$, Zejneba Pašić ${ }^{1,2}$ \\ ${ }^{1}$ Clinic for Neurology, University Clinical Center Tuzla, Prof. dr. Ibre Pašića bb, 75000 Tuzla, B\&H. \\ ${ }^{2}$ Faculty of Medicine University of Tuzla, Univerzitetska 1, 75000 Tuzla, BiH. \\ ${ }^{3}$ Centre for Neurology, Medical Centre Tuzla, Albina i Franje Herljevića 1, 75000 Tuzla, B\&H. \\ ${ }^{4}$ Research Centre of Epidemiology and Statistics, Sorbonne Paris Cité, Paris, France
}

\begin{abstract}
Introduction: Multiple sclerosis (MS) is a chronic, inflammatory, (auto)immune disease of the central nervous system (CNS). Neuropsychological disorders are quite common in patients with multiple sclerosis and reflect the quality of life of patients.

Objective: The objective of the study is to investigate the effect of neuropsychological disorders on the quality of life of patients with multiple sclerosis.

Methods: The prospective study included 135 subjects with MS and 50 healthy subjects. The subjects were divided into three groups: the first group consisted of 85 subjects who were ill for longer than one year, the second group consisted of 50 subjects with newly diagnosed MS, the third group consisted of 50 healthy subjects. Instruments for clinical evaluation were: Mini-Mental State Exam, The 36-Item Short Form Health Survey questionnaire (SF-36), and a battery of neuropsychological tests: The Wechsler Adult Intelligence Scale, The Revised Beta Examination, Raven's Colored Progressive Matrices, Wechsler Memory Scale, The Verbal Learning Test, The Rey-Osterrieth complex figure test, The Verbal Fluency Test. Results: The results from the battery of neuropsychological tests reveal that $40-60 \%$ of subjects with MS suffer from cognitive disorders. Visuospatial, visuoconstructive and visuoperceptive abilities are worse in the first group. Mnestic functions (the learning process, short-term and long-term memory, recollection, verbal-logical memory) were affected in both groups of subjects, in the range of $30-60 \%$. Poorer cognitive domains were found in the first group of subjects. Immediate working memory, attention, short-term and logical memory were worse in the first group of subjects. At the onset of the disease, $16 \%$ of subjects had verbal fluency disorders, and as the disease progressed, the disorders also become more pronounced. The results of the assessment of quality of life show that patients with poorer MMSE and poorer cognitive functions have poorer quality of life in physical and mental dimensions and the overall score.

Conclusion: Neuropsychological disorders in patients with MS are related to impaired mnestic functions, executive functions and attention. Cognitive disorders have a negative effect on the quality of life in patients with multiple sclerosis. Key words: multiple sclerosis, neuropsychological/cognitive disorders, quality of life
\end{abstract}

Correspondence:

Assistant Professor Aida Šehanović, MD, PhD, neuropsychiatrist

E-mail: aida.sehanovic@gmail.com 